\title{
INVESTIGATION OF GLASS PLATE FAILURE MECHANISM SUBJECTED TO COPPER AND STEEL PROJECTILE IMPACTS
}

\author{
QASIM H. ShaH AND KYaW M. AUng \\ Department of Mechanical Engineering, Faculty of Engineering, \\ International Islamic University Malaysia, \\ PO Box 10, 50728, Kuala Lumpur, Malaysia. \\ qasim.h.shah@gmail.com,hqasim@iium.edu.my
}

\begin{abstract}
A glass plate is typically subjected to impact by spherical copper and steel projectiles at low velocities. The glass failure features consisted of a central Hertzian cone made up of comminuted glass and a spider web like cracking pattern around the cone with circumferential and radial cracks. However, objective of this research was to determine if the damage caused by copper projectile impact compared to steel projectile impact was higher for the same kinetic energy (K.E.) projectiles and the reasons for this phenomenon. For the constant K.E. impact, copper projectile apparently caused higher damage in a glass plate. Higher damage was attributed to projectile contact duration and the contact area between the projectile and the glass plate. Finite element analysis using LS-DYNA based upon maximum principal strain failure criterion for laminated glass model was able to predict the failed material under the impact location and the cracking pattern in the glass plate for a biased meshing scheme. Radial cracks in glass target were reported to be $15 \%$ higher for copper projectile impact than the steel projectile impact.
\end{abstract}

ABSTRAK: Kepingan kaca dikenakan impak oleh projektil kuprum dan keluli berbentuk sfera pada halaju rendah. Ciri-ciri kegagalan kaca terdiri daripada kon berpusat Hertzian yang melibatkan kaca yang hancur dan corak pecahan berbentuk sesawang lelabah pada keliling kon dengan retakan lilitan dan jejarian. Tujuan penyelidikan adalah untuk menentukan sebab bagaimana dengan projektil tenaga kinetik yang sama, kerosakan yang diakibatkan oleh impak projektil kuprum berbanding dengan impak projektil keluli adalah lebih tinggi. Untuk impak tenaga kinetik yang malar, projektil kuprum didapati menyebabkan kerosakan yang lebih ke atas kepingan kaca. Kerosakan lebih disebabkan oleh tempoh sentuhan projektil dan kawasan sentuhan di antara projektil dan kepingan kaca. Analisis unsur terhingga menggunakan LS-DYNA berdasarkan kriteria kegagalan terikan utama maksima untuk model kaca berlamina. Kaedah ini berupaya menjangkakan kegagalan objek pada lokasi impak dan corak retakan pada kepingan kaca untuk skim berjejaring terpincang. Retakan berjejari pada sasaran kaca didapati $15 \%$ lebih tinggi untuk impak projektil kuprum berbandingkan dengan impak projektil keluli.

KEYWORDS: comminuted material; radial cracks; LS-DYNA; glass failure; biased mesh

\section{INTRODUCTION}

The motivation for the present study originated from a previous work [1] where brass, steel, and lead projectiles were used to investigate the damage and failure in an unconfined granite rock edge. The differences in damage and failure in rock specimen were significant under the impact of three different material projectiles but less clear due to rock's opaque nature. In the present work a glass plate was subjected to impact by brass and steel projectiles and clear differences in crack density and fragmentation were recorded. A similar study [2] was performed on ceramic tiles where a confined ceramic plate was 
subjected to brass, steel, and aluminum projectiles impact to determine the threshold parameters like velocity, contact pressure, and forces to initiate the damage. The crack densities were reported to be higher for brass impact on the ceramic tile while steel and aluminum projectiles caused very little damage in ceramic tiles due to higher strength of ceramic.

Due to great interest in the damage and failure resistance of glass materials, numerous investigations have been carried out. A material model was proposed [3] to be able to represent the damage caused to a soda lime glass target by subjecting a glass plate to a spherical and cylindrical projectile impact on its edge. The model was able to account for the velocities of longitudinal and transverse wave propagation in the plate. As far as the predictions of the size and the shape of the coherent-damage zones (i.e. the zones containing large number of fine cracks) are concerned, the model agreed well with the experimental evidence only at relatively short post-impact times. The discrepancy in computation and the experimental work was attributed to the influence of the target fixture induced stresses.

An explicit approach to predict crack nucleation, propagation, branching, and linking was proposed to account for realistic fragmentation patterns during the failure of a glass rod on impact by refuting the continuum mechanics approach due to its inherent drawbacks like crack propagation dependency on mesh patterns [4]. It was claimed that the proposed model (based on cohesive law) would not be mesh dependent and should be able to predict each crack in the failed structure.

The difficulty in predicting cracks and crack propagation paths precisely in the glass like structures under impact is evident from numerous observations. One example is provided by [5] where a glass plate was subjected to a mild steel rod impact and the failure of the glass plate and damage to the steel rod was observed in the experiments. The model predicted the steel rod damage for normal and oblique impact $\left(45^{\circ}\right)$ and was also able to predict the transition from dwell to penetration however the model did not predict the detailed crack patterns observed in the experiments.

The results of a detailed experimental work have been reported [6] where a series of experiments were conducted by impacting various bullets on glass blocks with and without backing plate. Many parameters including residual velocity as a function of impact, scale size and time dependency of glass damage and failure were studied. Penetration responses for varying caliber bullets were recorded. Bullet erosion was pointed out to be a good measure of the penetration resistance of glass material. The main aim of the experimental investigation was to determine the time dependency of glass failure under ballistic impacts. The observations were consistent with the time dependency associated with failure of glass which occurs on the time scale of ballistic impact. Rate of damage was observed to be a function of the overstress. Summing up of all the results showed the importance of the related research work which was declared to remain an active research field.

Experimental work has determined that when Soda-Lime glass is subjected to sufficiently high axial stress (pressure), it displays a non linear mechanical response and deformation irreversibility (inelasticity). This portion of material behavior is normally avoided in material models for glass which may affect negatively on the wave propagation in the glass material. Inclusion of non linear effects in the material model for Soda-Lime glass may not affect the spall resistance however it can yield beneficial effects in terms of linear momentum and kinetic energy reduction effects [7]. 
The intact and pre-damaged Borosilicate glass specimens were tested at high confinement pressures to characterize their material behavior at high impact velocities to determine the material parameters for Drucker-Prager (DP) and Mohr-Coulomb (MC) models [8]. A potential advantage of MC model compared with DP model was found to be its ability to predict failure angle.

Laminated glass window performance to resist flying wood block debris penetration was evaluated [9] using experiments. Numerical simulations were carried out to predict crack patterns with some limitations owing to the regular quad meshing for the window glass. A pedestrian head impact on a windshield in a car accident was analyzed [10] using the finite element method. Circumferential and radial crack patterns around the impact location were predicted but no clear evidence was provided.

Based upon previous studies where a borosilicate glass block was tested under shear/compression loading using SHPB was modeled in explicit finite element analysis and the damage caused in the sample was predicted [11]. The specimen was loaded into SHPB at an oblique angle so that upon impact the dominant mode of failure was shearing. Maximum shear stress criterion was used for failure assessment under continuum damage mechanics approach. Reasonably good comparisons between prediction and experimental work were obtained.

Hyper velocity impact experiments were performed [12] on Silicon dioxide $\left(\mathrm{SiO}_{2}\right)$ glass to investigate the damage process details and failure sequence with the help of high speed camera imaging. Formation of radial cracks was attributed to projectile kinetic energy.

Glass is known as an effective armor material against shaped charge jets while its performance against conventional long rod projectile is mediocre. To determine the glass resistance against long rod penetration, experimental work [13] was carried out at high velocity and it was revealed that as the long rod tip comes into contact with the glass, a wave travels in the target ahead of the penetrator but when the velocity of the long rod is sufficiently higher than the wave velocity the penetrator comes into direct contact with the intact material causing damage. That was found to be the reason of the decreased of glass resistance against long rod penetrator at velocity range of $3.6 \mathrm{kms}^{-1}$ and above. Therefore the glass resistance should be measured only at hypervelocity to ascertain the actual resistance of ceramics. A long gold rod of $1 \mathrm{~mm}$ diameter and a length of $50 \sim 70 \mathrm{~mm}$ was struck by a glass cylinder of $20 \mathrm{~mm}$ diameter and a length of $15 \sim 20 \mathrm{~mm}$ at high velocities so that the gold rod penetrates the cylindrical glass specimen [14]. Long rod penetration process was measured using optical and X-Ray techniques. It was observed that at initial stage of contact between gold rod and glass specimen the failure front (due to wave propagation) velocity was higher than the penetration velocity but as the projectile velocity was increased the distance between the failure front and the long rod tip was reduced. 3D stress/strain state was found to be one of the governing parameter in penetration process.

A semi-empirical method was proposed [15] to evaluate the damage parameters related to failure wave formation based on the analysis of free surface velocity history using linear acoustic theory. Shock compression experiments were conducted on K9 and Z71 glasses and it was revealed that the damage strongly depends upon the glass material.

Cell phone drop test results were reported [16] regarding the LCD glass damage. It was found that for the direct contact (horizontal orientation) between the LCD and the floor caused severe damage to the LCD screen. It was claimed that the numerical results 
confirmed the experimental evidence. Design changes were suggested based upon Taguchi method.

Maximum stress failure criterion was implemented [17] in an existing explicit finite element code to simulate the head form impact on a laminated windshield to assess the windshield failure. Analytical impact resistance model was developed and used to examine the impact breach consequences of the experimental study on float glass samples [18]. A time dependent failure model was added to this model and it was found that the difference between this model and the common fracture resistance of glass was very large.

Windshield model using the regular quad mesh was analyzed [19] for head form impact which generated somewhat unrealistic crack patterns. Instead of circular and radial crack patterns, vertical and horizontal crack lines were predicted. It was found that the directionally biased orientation mesh can serve the purpose of reproducing realistic crack patterns.

Glass failure model was developed [20] to account for the edge-on impact on a glass plate to assess the damage caused due to longitudinal and transverse waves and compared to experimental results obtained in literature. When the same model was tested by [21] it was found that the model agreed with experimental results of gold rod penetration into a cylindrical glass specimen by invoking the third deviatoric stress invariant (J3), but uncertainties regarding the published model constants were raised as the constants had to be estimated. It seemed clear that time dependent failure did not replicate accurately the mechanics of glass damage. It was suggested that probably the impact conditions were tuned to give reasonable results. Therefore different impact velocities should be used to check the validity of the proposed model.

Impact tests on a float glass plate were conducted [22] using two methods. In the first method a ball drop test was performed at low loading rate while in the second method a long rod was impacted against a similar glass specimen using Split Hopkinson Pressure Bar equipment (high loading rate). For increased loading rate, a large number of cracks were generated. Damage parameters were suggested to control the glass damage depending upon the variation of the glass volume due to impact.

A computational model of impact damage in brittle materials was developed by [23] that successfully predicted the dynamic fracture and fragmentation of brittle materials subjected to impact load. Radial cracks formation was achieved and it was found that only $1.5 \%$ of the projectile K.E. was responsible for cracking, while rest of the K.E. was spent in the projectile damage.

The effect of back plate on the cone formation in glass plate subjected to impact has been discussed in [24] where PMMA, PU, and Aluminum back plates were used to support the glass specimen. Hertzian cone crack formation in thin glass plate was attributed to high velocity projectile impact [25].

\section{EXPERIMENTAL WORK}

A $100 \mathrm{~mm}$ square glass plat with $7.8 \mathrm{~mm}$ thickness was mounted on a backing plate with the help of an adhesive tape. The glass plate was subjected to spherical projectile (9.51 mm diameter) impact. The impact tests were conducted using steel and copper projectiles. The impact velocities of steel and copper projectiles were adjusted so that they generated a constant value of kinetic energy in both projectiles. As a result of impact the glass plate shattered into a combination of small and large fragments consisting mainly of 
comminuted glass material in the shape of a hertzian cone [25] at the projectile impact point. Circumferential and radial cracks appeared around the comminuted cone. The damage parameters obtained from steel and copper projectile impacts are shown in Table 1.

Table 1: Projectile velocities and the damage of glass plate.

\begin{tabular}{cccc}
\hline PROJETILE & $\begin{array}{c}\text { VELOCITY } \\
\left(\mathbf{m s}^{-\mathbf{1}}\right)\end{array}$ & $\begin{array}{c}\text { NO. OF RADIAL } \\
\text { CRACKS }\end{array}$ & $\begin{array}{c}\text { COMMINUTED CONE } \\
\text { SIZE }(\mathbf{m m})\end{array}$ \\
\hline STEEL & 74 & 19 & $35-40$ \\
COPPER & 66 & 30 & $25-30$ \\
COPPER & 71 & 33 & $35-40$ \\
\hline
\end{tabular}

\subsection{Steel Project Impact}

Glass plate was subjected to a steel projectile impact at $74 \mathrm{~ms}^{-1}$. The projectile velocity was chosen so that there was a moderate damage caused to the glass plate so that it is easier to make necessary measurements on the broken specimens. It was found that very high velocity projectile impact for the selected glass specimen dimensions and mounting method results in complete destruction of the glass specimen leaving very little evidence to investigate. A sample of glass plate specimen is shown in Fig. 1 after steel projectile impact where the central cone with comminuted material and circumferential and radial cracks are visible.

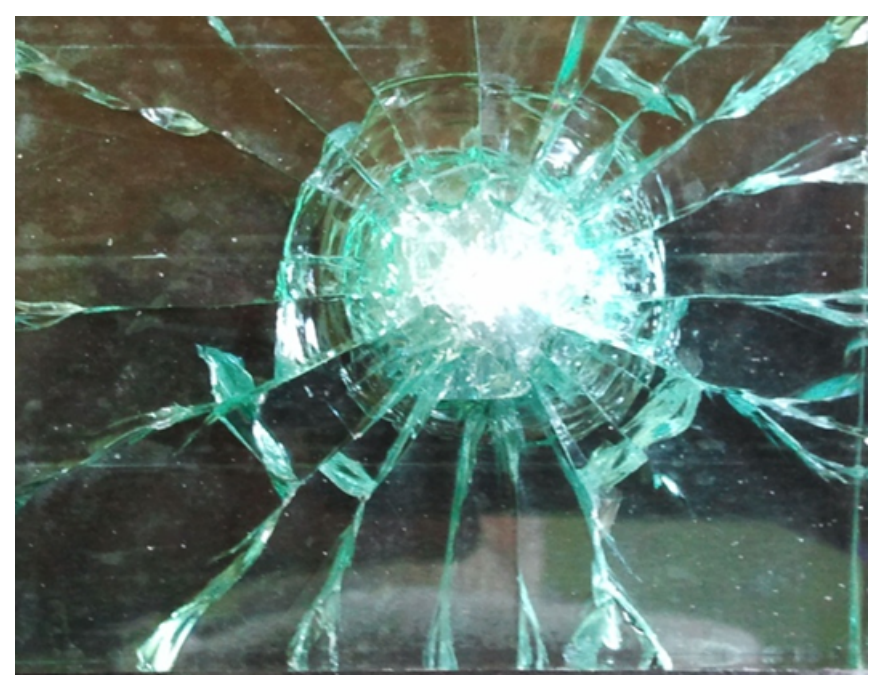

Fig.1: Glass plate after steel projectile impact at $74 \mathrm{~ms}^{-1}$ showing comminuted cone at the center followed by circumferential cracks around the cone and large radial cracks.

Occasionally a link up crack is also visible linking two radial cracks.

The number of radial cracks varied between 18 and 20 in total. Some cracks linking two radial cracks are occasionally visible at a larger distance from the center. These cracks were responsible for shattering away of the glass plate corners for higher projectile velocities. The cone generated in a glass specimen upon steel projectile impact is shown in Fig. 2. 


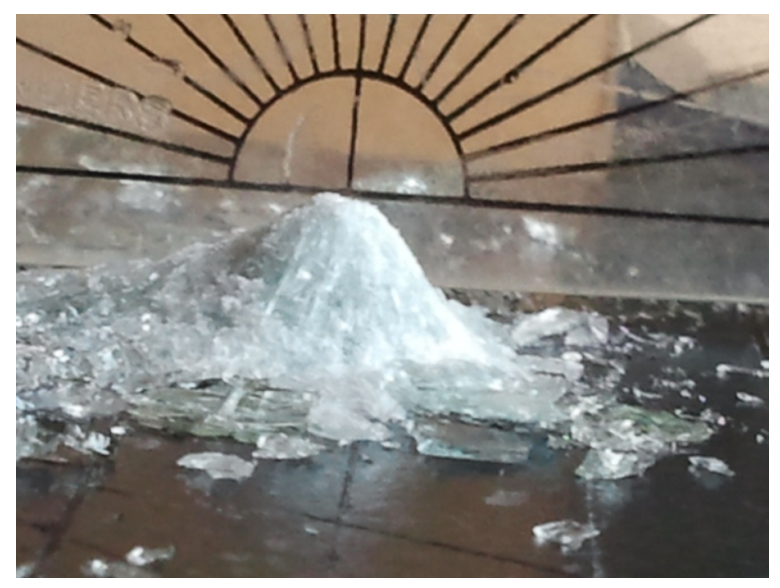

Fig. 2: Cone generated in the glass sample upon steel projectile impact.

\subsection{Copper Projectile Impact}

Under this category the impact tests were conducted at two different velocities of 66 and $71 \mathrm{~ms}^{-1}$ respectively. Impact velocity of $66 \mathrm{~ms}^{-1}$ was chosen so that the kinetic energy was same as that of steel projectile. Although the diameter of both copper and steel projectiles was the same yet their kinetic energy varies at the same velocity because of the difference in their material densities. Glass sample subjected to $66 \mathrm{~ms}^{-1}$ impact velocity by copper projectile is shown in Fig. 3.

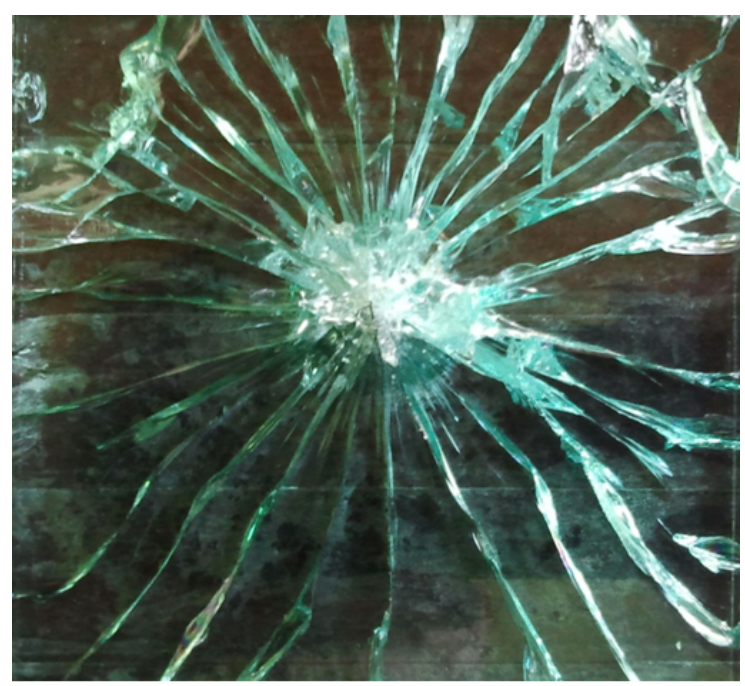

Fig. 3: Glass sample subjected to copper projectile impact at $66 \mathrm{~ms}^{-1}$. Number of radial cracks are much higher than in the event of steel projectile impact.

The number of radial cracks generated due to copper projectile impact ranged from 29 to 31. The damage and failure of glass plate subjected to copper projectile impact at $71 \mathrm{~ms}^{-1}$ is also shown in Fig. 4 while the cone generated at the center of the plate is shown in Fig. 5. The difference in the number of radial cracks resulting from $71 \mathrm{~ms}^{-1}$ compared to $66 \mathrm{~ms}^{-}$ ${ }^{1}$ impact shows a small variation. 


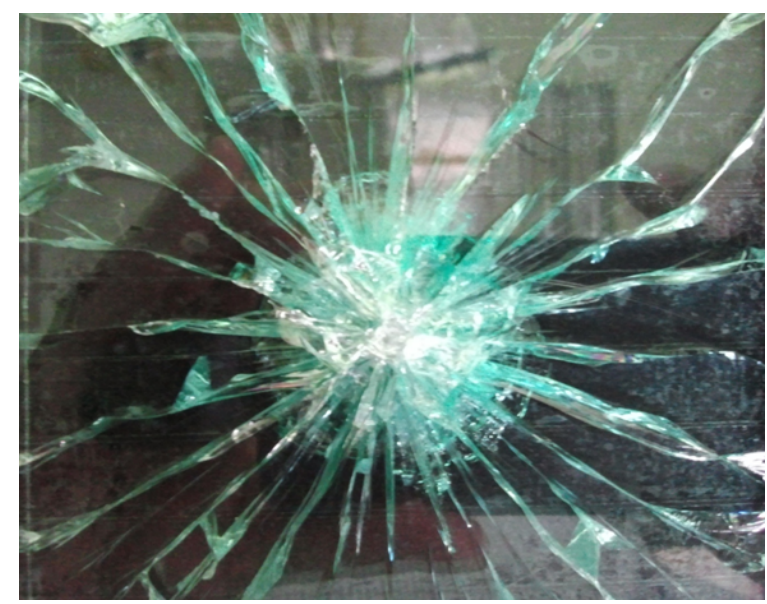

Fig. 4: The damage and failure of glass plate subjected to copper projectile at a velocity of $71 \mathrm{~ms}^{-1}$.

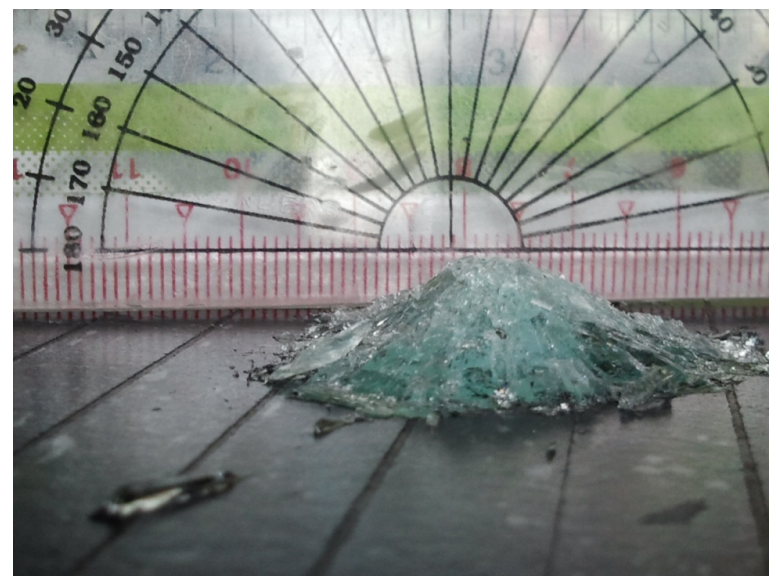

Fig. 5: Cone resulting from copper projectile impact at $71 \mathrm{~ms}^{-1}$.

\section{NUMERICAL ANALYSIS}

The glass plate was modeled in LS-DYNA using laminated glass model (*Mat_Laminated_Glass) with 40014 shell elements with through the thickness 3 point integration. The central portion of the glass plate was meshed using biased mesh so that circumferential and radial crack propagation was favored. It was found that simple quad mesh is unable to reproduce the realistic crack patterns in the glass plate. The meshed plate is shown in Fig. 6 along with backing plate and the metal projectile.

A backing plate was also meshed with comparatively coarse mesh. Above mentioned steel or copper projectile was meshed with fine solid elements. The average mesh size of glass plate ranged between 0.35 and $0.65 \mathrm{~mm}$. As the shell thickness in the present work was equal to the glass plate thickness which is $7.8 \mathrm{~mm}$, further refinement results in element aspect ratio problems. Material model for backing plate and the metal projectile were modeled using elastic plastic model (*Mat_Plastic_Kinematic) with their respective material properties. For the glass plate the mass density used was $2530 \mathrm{kgm}^{-3}$, an Elastic modulus of $70 \mathrm{GPa}$, and a Poisson's ratio of 0.17 was used. The yield strength for tempered glass was set at $150 \mathrm{MPa}$. Most of the material properties used to represent glass material have been taken from [19]. The failure criterion used in this work was based on 
maximum principal strain which was obtained through many trials and an appropriate value that produced approximate crack patterns was used in all three impact cases. To achieve the crack patterns an element deletion criterion is utilized. This was done using (*Mat_Add_Erosion) in LS-DYNA. The material properties used in FEA analysis are shown in Table 2.

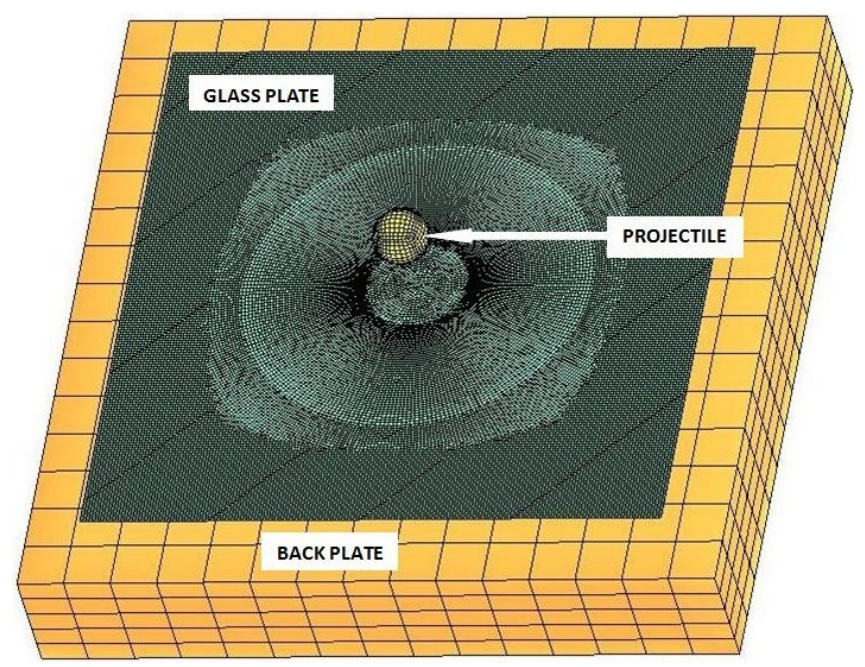

Fig. 6: FEA mesh used for simulations showing back plate, glass plate, and projectile.

Table 2: Material properties.

\begin{tabular}{cccccc}
\hline MATERIAL & $\begin{array}{c}\text { Density } \\
\left(\mathbf{k g m}^{-3}\right)\end{array}$ & $\begin{array}{c}\text { Elastic } \\
\text { Modulus (GPa) }\end{array}$ & $\begin{array}{c}\text { Yield Strength } \\
(\mathbf{M P a})\end{array}$ & $\begin{array}{c}\text { Tangent } \\
\text { Modulus } \\
(\mathbf{G P a})\end{array}$ & $\begin{array}{c}\text { Failure } \\
\text { Criterion }\end{array}$ \\
\hline Glass & 2530 & 70 & 150 & - & $\begin{array}{c}\text { Max Failure } \\
\text { Strain } \\
(2.0 \mathrm{e}-6)\end{array}$ \\
$\begin{array}{c}\text { Steel (Projectile) } \\
\text { Copper (Projectile) }\end{array}$ & 7800 & 200 & 170 & 1.0 & - \\
$\begin{array}{c}\text { Aluminum } \\
\text { (Back Plate) }\end{array}$ & 8900 & 117 & 250 & 0.9 & - \\
& 2700 & 70 & 267 & 0.5 & - \\
\hline
\end{tabular}

The glass plate is subjected to the copper projectile impact at $66 \mathrm{~ms}^{-1}$ and the steel projectile at $74 \mathrm{~ms}^{-1}$ respectively. At these velocities their equivalent K.E. is calculated to be same as $9.61 \mathrm{~J}$.

Damage and failure of glass plate subjected to steel projectile impact $\left(74 \mathrm{~ms}^{-1}\right)$ is shown in Fig. 7 while damage for glass plate when subjected to copper projectile impact $\left(66 \mathrm{~ms}^{-1}\right)$ can be seen in Fig. 8 respectively. 


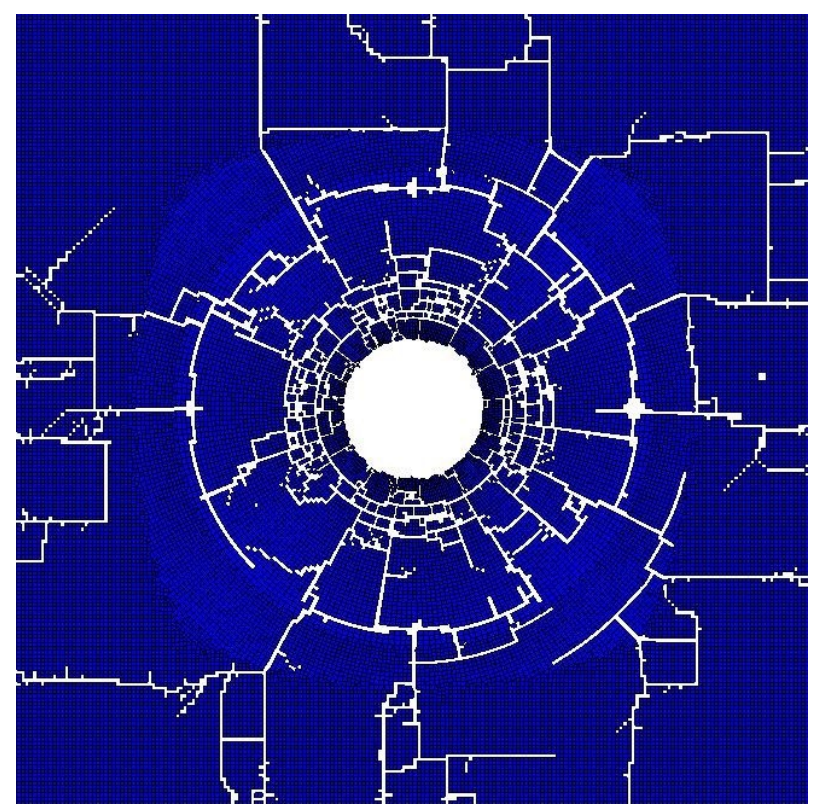

Fig. 7: Crack patterns obtained for the steel projectile impact $\left(74 \mathrm{~ms}^{-1}\right)$.

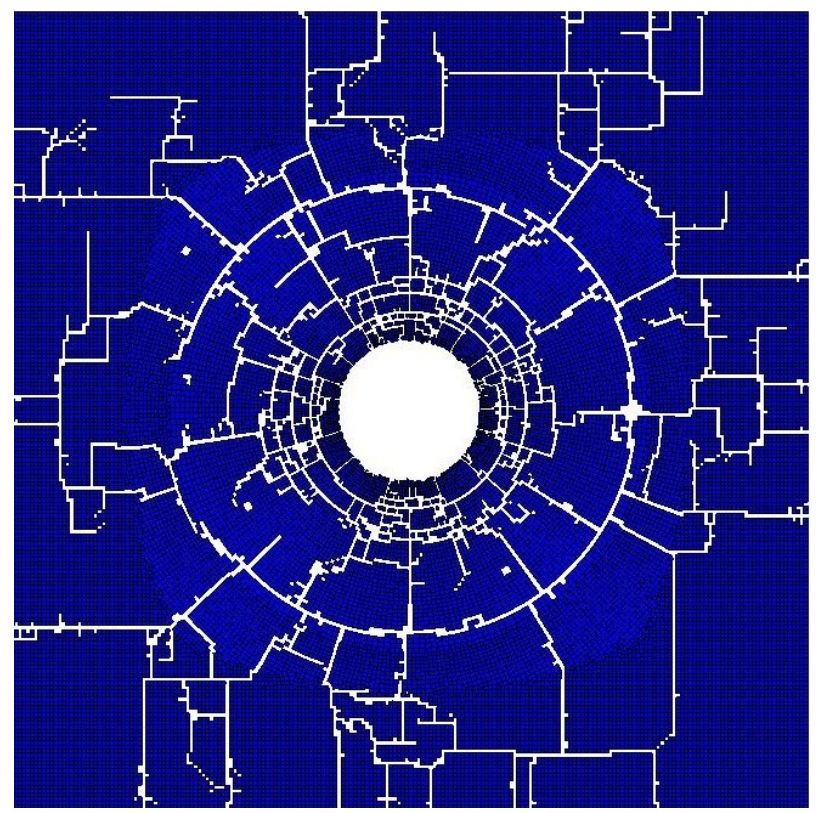

Fig. 8: Damage of glass plate showing comparatively higher number of cracks for copper projectile impact $\left(66 \mathrm{~ms}^{-1}\right)$.

A careful observation of these two figures reveals that number of radial crack obtained for steel projectile impact are roughly 18 while for the copper projectile impact they range between 29 and 31 which can be easily validated from the experimental evidence. This means that LS-DYNA was able to predict the number of radial cracks very closely. However as the cracks confronted the regular quad mesh on their way beyond biased mesh zone where the biased mesh terminates into regular quad mesh the cracks follow the mesh direction instead of following a straight line until the end. This 
discrepancy in crack path prediction proves the fact that biased meshing practice should be preferred over regular quad mesh.

The empty hole in the middle shows the region for comminuted material which has been eroded from the mesh. The circumferential crack patterns in immediate vicinity of the comminuted cone material were successfully predicted in the glass specimens as shown in the above mentioned figures.

Copper projectile impact was also modeled at $71 \mathrm{~ms}^{-1}$ and the crack pattern for those tests is shown in Fig. 9. Cracks in this particular case are densely populating the glass specimen. Glass plate corners show a separation from the main body which was also observed in related experiments.

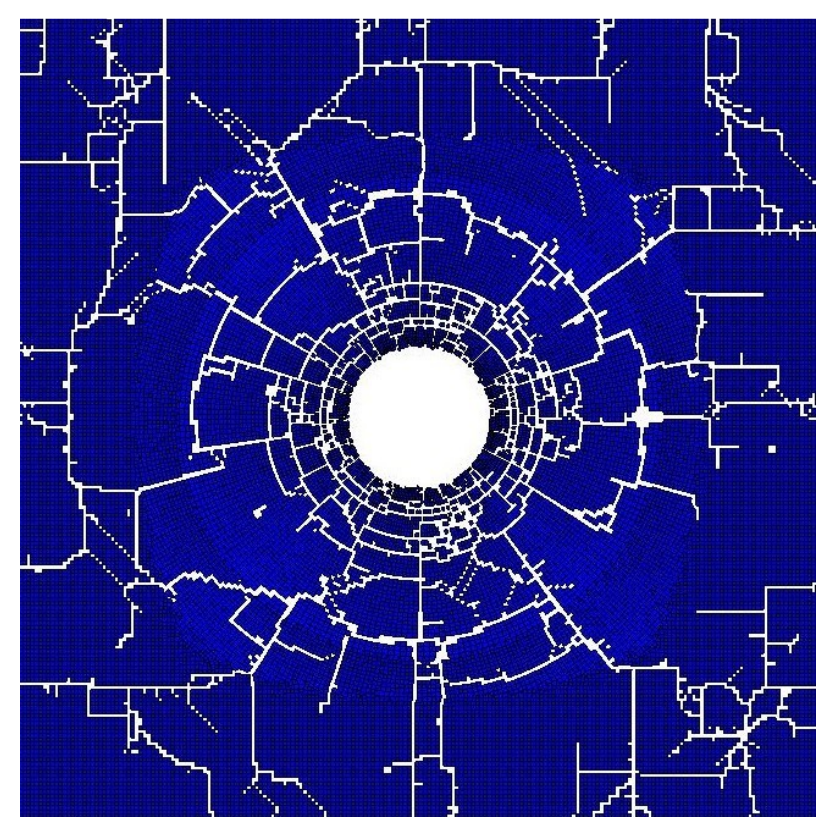

Fig. 9: Crack patterns for copper projectile impact at $71 \mathrm{~ms}^{-1}$. Shattering of the four corners is clearly visible.

The impact force between steel projectile and the glass plate obtained from FEA simulation is shown in Fig. 10 while the impact force for copper projectile impact is shown in Fig. 11 respectively. The impact force for copper projectile is slightly higher than steel projectile. The peak impact force for copper projectile is delayed by $15 \mu$ sec. This may be due to the fact that a higher contact area is involved during copper projectile impact which deforms significantly compared to steel projectile which suffers only minor scratches. The energy absorbed by glass specimen under copper projectile impact was observed to be $3.125 \%$ higher than in case of steel projectile impact. 


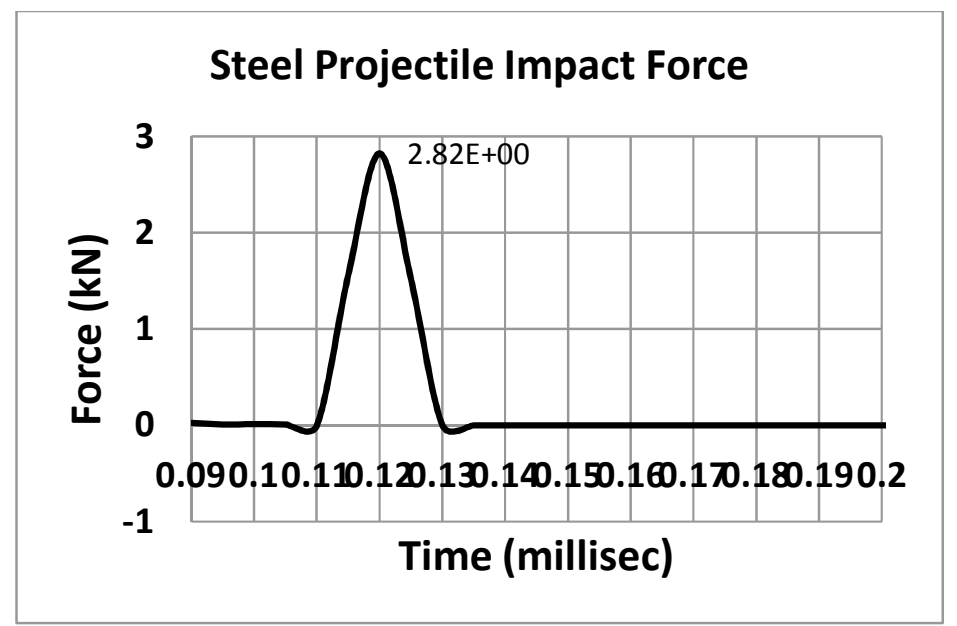

Fig. 10: The impact force between steel projectile and the glass plate for a projectile velocity of $71 \mathrm{~ms}^{-1}$.

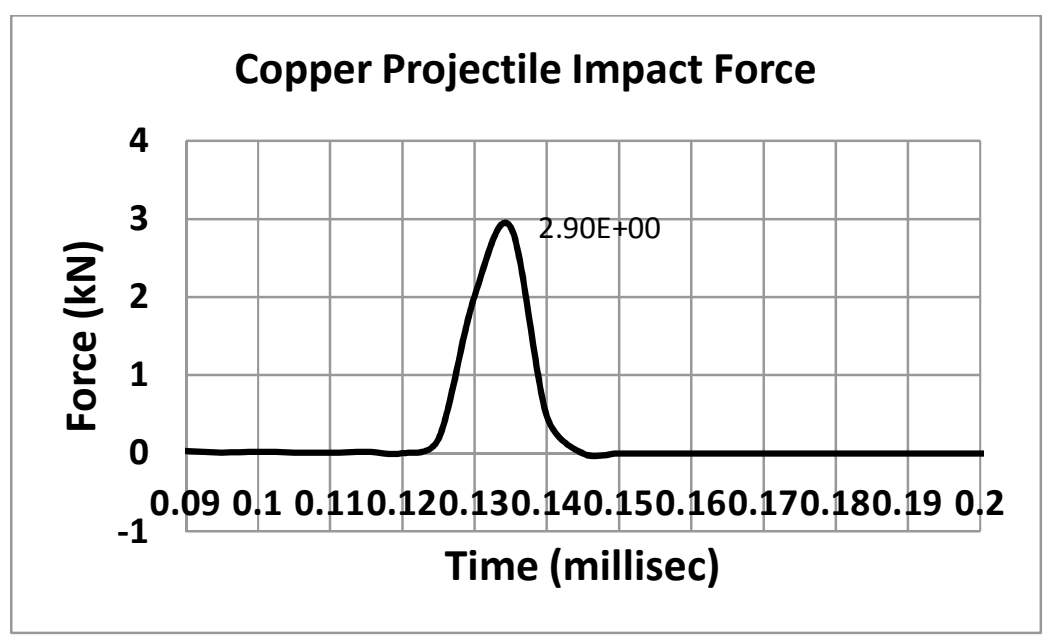

Fig. 11: Impact force between copper projectile and the glass plate for a projectile velocity of $66 \mathrm{~ms}^{-1}$.

\section{DISCUSSION}

In a previous work [1] damage and failure of unconfined granite rock under metal projectile impact were studied. Damage caused to rock specimen showed clearly that the copper projectile causes significantly higher damage compared to a steel projectile however as the rock is an opaque material it is not easy to determine the extent of crack propagation in it. Glass on the other hand is transparent and the crack patterns can be observed very clearly to assess the damage. Moreover the study of glass failure and damage is of great interest to the engineering community and it remains an active research field [6].

In the present work a glass plate was subjected to steel and copper projectile impact at 71 and $66 \mathrm{~ms}^{-1}$. The reason to adopt these projectile velocities was the fact that although the diameter of both projectiles was same $(9.51 \mathrm{~mm})$ but accelerating them at a constant velocity would result in different kinetic energies. Therefore velocities that provide same K.E. were used in the experiments. Steel projectile resulted in a cone with comminuted 
glass material under the impact point. Around the cone region circumferential cracks were observed as shown in Fig. 1 and Fig. 3. After circumferential cracks radial cracks that actually originated from the cone region propagated until the farthest end of the glass plate. Some of the cracks however terminated on their way before reaching the outer boundaries.

The comminuted region for steel projectile impact was observed to be slightly greater than the copper projectile impact however the number of radial cracks resulting from the copper projectile impact were 1.63 times higher than the steel projectile impact. This shows that apart from projectile velocity, K.E., and other factors the projectile material is also an important factor to be considered in the failure of the glass like brittle materials subjected to impact. The difference in the number of radial cracks may be attributed to the deformation of projectile material and the area of contact which is significantly different for steel and copper projectiles. Steel and copper projectiles were observed after impact and it was found that the copper projectile underwent large plastic deformation compared to insignificant scratches on the steel projectile surface. Steel projectile bounces back after impact but copper projectile continues to deform plastically after impact. The damage in terms of comminuted material right under the nose of steel projectile is intense and instantaneous and the radial cracks generated by steel projectile impact have the tendency to be arrested earlier because of the sudden cut back of energy due to bouncing back of the projectile. One the other hand the energy imparted by the copper projectile is more gradual that results in lesser comminuted material at the impact site but the radial cracks continue propagating under a constant supply of energy.

Numerically reproducing the damage and failure in brittle materials is a great challenge [9] at present. In this field a very recent paper [26] has shown some promising results. The authors have used Peridynamics to model the crack propagation in thin glass samples with thin polycarbonate backing plate. In the present work LS-DYNA was used to model the glass plate using possibly very fine mesh. The directionally biased mesh was able to reproduce the overall damage and failure quite successfully. As the biased mesh terminated into a regular quad mesh near the outer edges the cracks immediately started following the regular mesh directions (either horizontal or vertical). This shows that with existing commercial hydrocodes the realistic crack propagation direction is only possible with providing directionally biased mesh. LS-DYNA was able to reproduce the damage and failure in terms of comminuted material, circumferential, and radial cracks.

Figure 10 and 11 show the impact force computed by FEA between the projectile and the glass plate. The impact force in case of copper projectile is slightly greater compared to the steel projectile impact. The peak for impact force for copper projectile impact shows a delay of $15 \mu \mathrm{sec}$. This delay shows the time during which copper projectile undergoes plastic deformation and the contact area between deforming projectile nose and the glass is increased. The energy absorbed by glass plate was found to be $3.125 \%$ higher in case of copper projectile impact. Further investigations are suggested to determine the exact cause of higher number of radial cracks observed under the copper projectile impact.

In Fig. 12 the broken glass specimens due to impact by copper and steel projectile impact are shown as an evidence. It is clearly visible that the damage and failure caused by copper specimen in terms of number of cracks is higher when compared to steel projectile. This increase was observed to be about $15 \%$. 


\section{COPPER PROJECTILE IMPACT}
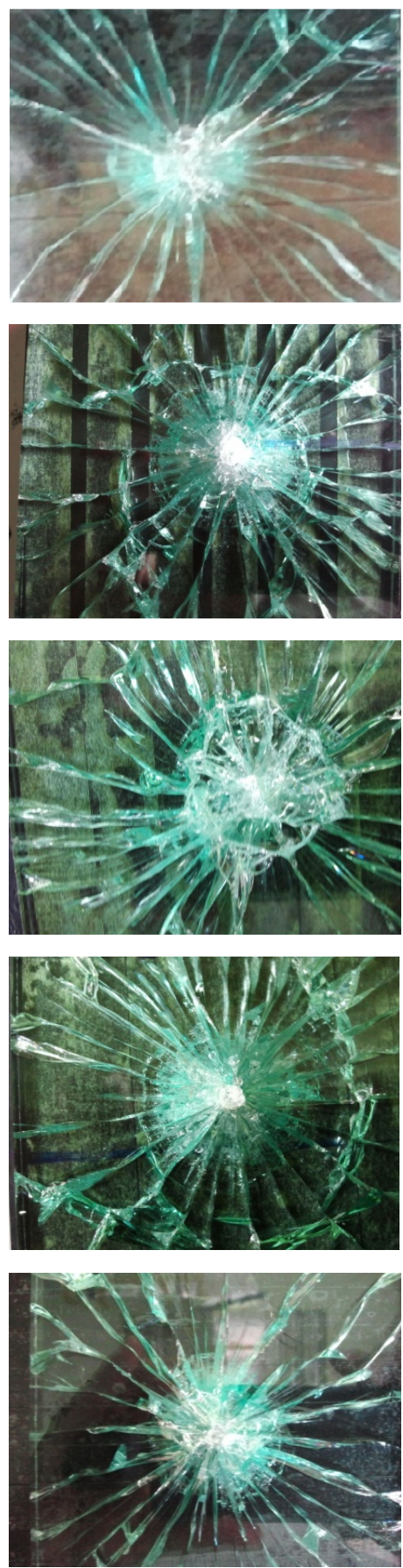

STEEL PROJECTILE IMPACT
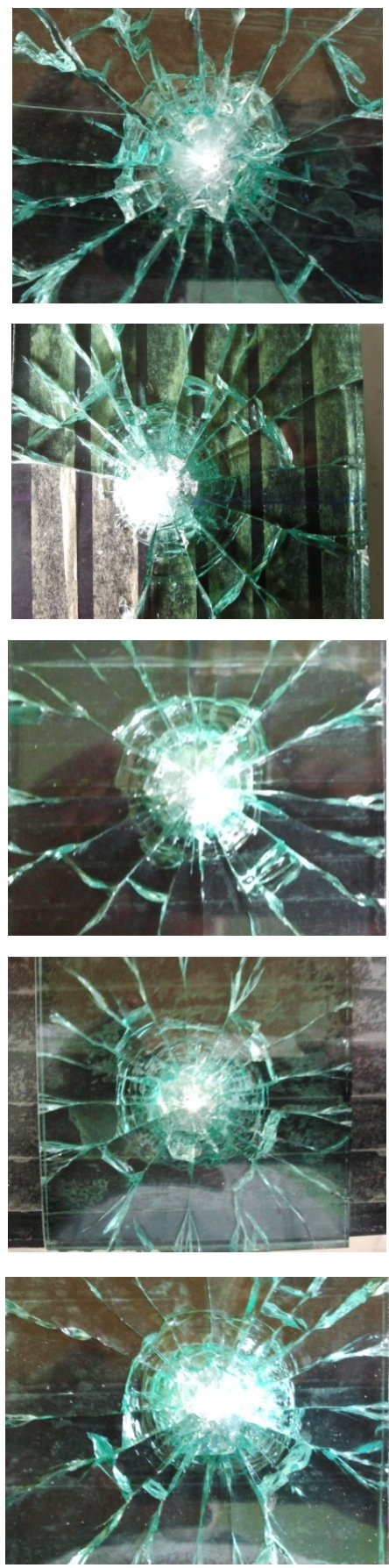

Fig. 12: Damage caused by copper projectile impact compared to steel projectile impact.

\section{CONCLUSION}

Glass plate was subjected to constant K.E. steel and copper projectile impacts at 74 and $66 \mathrm{~ms}^{-1}$ respectively. The failure of glass specimens included comminuted cone material at the point of impact. Further away from the center the circumferential and radial 
cracks were responsible for the failure of the glass plate. The failure of glass plate was compared for steel and copper projectile impacts. Numerical simulations were carried out using LS-DYNA to predict the failure process. The following conclusions were made:

- Under constant K.E. projectile impact the damage caused by comparatively softer projectile was higher in the glass plate (brittle material) when compared to the stiffer projectile.

- The higher damage in the glass can be attributed to the delayed contact time and contact area increase between the colliding bodies.

- Using directionally biased mesh to model the glass plate enables successful reproduction of realistic crack patterns in the glass material.

- When directionally biased mesh terminates into regular quad mesh the cracks may follow the mesh leaving their true path observed experimentally.

- The average number of cracks in the glass target were found to be $15 \%$ higher in case of copper projectile when compared to the steel projectile.

\section{ACKNOWLEDGEMENT}

The author is highly obliged to the Research Management Center (RMC), International Islamic University Malaysia for providing research grant [EDWA11-117-0908] for the completion of this work.

\section{REFERENCES}

[1] Shah, Q. H., Hamdani, A. The damage of unconfined granite edge due to the impact of varying stiffness projectiles. International Journal of Impact Engineering, 59(2013):11-17.

[2] Compton, B. G., Gamble, E. A., Zok, F. W. Failure initiation during impact of metal spheres onto ceramic targets. International Journal of Impact Engineering, 55(2013):11-23.

[3] Grujicic, M., Pandurangan, B., Coutris, N., Cheeseman, B.A., Fountzoulas, C., Patel, P., Strassburger, E. A ballistic material model for starphire, a soda-lime transparent-armor glass. Materials Science and Engineering A, 491(2008):397-411.

[4] Repetto, E.A., Radovitzky, R., Ortiz, M. Finite element simulation of dynamic fracture and fragmentation of glass rods, Computer. Methods Applied. Mechanical. Energy, 183(2000):314.

[5] Forde, L.C., Proud, W.G., Walley, S.M., Church, P.D., Cullis, I.G. (2010) Ballistic impact studies of a borosilicate glass. International Journal of Impact Engineering, 37(2010):568578.

[6] Anderson, Jr. C.E., Weiss, C.E., Chocron, S. "Impact Experiments into Borosilicate Glass at Three Scale Sizes." "Journal of Applied Mechanics 78.5 (2011): 051011.

[7] Grujicic, M., Bell, W.C., Pandurangan, B., Cheeseman, B.A., Patel, P., Gazonas, G.A. "Inclusion of material non-linearity and inelasticity into a continuum-level material model for soda-lime glass." Materials and Design, 35 (2012): 144-15.

[8] Chocron, S., Anderson, Jr. C.E., Dannemann Arthur, K.A., Nicholls, E. Characterization of Borosilicate Glass Through Confined Compression Testing with Numerical Validation. US Army Tank-Automotive Research, Development, and Engineering Center, Warren, MI 48397-5000, (2009).

[9] Zhang, X., Hao, H., Ma, G. "Laboratory test and numerical simulation of laminated glass window vulnerability to debris impact." International Journal of Impact Engineering, 55(2013):55-49.

[10] Xu, J., Li, Y. Crack analysis in PVB laminated windshield impacted by pedestrian head in traffic accident. International Journal of Crashworthiness, 14.1(2009):63-7. 
[11] Sun, X., Liu, W., Chen, W., Templeton, D. "Modeling and characterization of dynamic failure of borosilicate glass under compression/shear loading." International Journal of Impact Engineering, 36(2009):226-234.

[12] Kawaia, N., Tsurui, K., Moriguchi, K., Hasegawa, S., Sato, E. "Damage Evolution in SiO2 Glass Subjected to Hypervelocity Impact." Procedia Engineering, 58(2013):702-08.

[13] Zilberbrand, E. L., Vlasov, A. S., Cazamias, J. U., Bless, S. J., Kozhushko, A. A. "Failure wave effects in hypervelocity penetration". International Journal of Impact Engineering, 23(1999):995-1001.

[14] Behner, T., Anderson Jr., C.E., Orphal, D.L., Hohler, V., Moll, M., Templeton, D.W. "Penetration and failure of lead and borosilicate glass against rod impact." International Journal of Impact Engineering, 35(2008):447-56.

[15] He, H., Jing, F., Jin, X. "Evaluating the damage in shock compressed glass coupling with VISAR measurement." International Journal of Impact Engineering, 25(2001):599-605.

[16] Hwan, C.L., Lin, M.J., Lo, C., Chen, W.L. "Drop tests and impact simulation for cell phones." Journal of the Chinese Institute of Engineers, 34.3(2011):337-346.

[17] Pyttel, T., Liebertz, H., Cai, J. "Failure criterion for laminated glass under impact loading and its application in finite element simulation." International Journal of Impact Engineering, 38(2011):252-63

[18] Grady, D.E. "Impact breach and fragmentation of glass plate." International Journal of Impact Engineering, 38(2011):446-50.

[19] Peng, Y., Yang, J., Deck, C., Willinger, R. "Finite element modeling of crash test behavior for windshield laminated glass." International Journal of Impact Engineering, 57(2013):2735.

[20] Grujicic, M., Pandurangan, B., Coutris, N., Cheeseman, B.A., Fountzoulas, C., Patel, P., Templeton, D.W., Bishnoi, K.D. "A simple ballistic material model for soda-lime glass." International Journal of Impact Engineering, 36(2009):386-401.

[21] Anderson Jr., C.E. Holmquist, T.J. "Application of a computational glass model to compute propagation of failure from ballistic impact of borosilicate glass targets." International Journal of Impact Engineering, 56(2013):2-11.

[22] Bouzid, S., Nyoungue, A., Azari, Z., Bouaouadja, N., Pluvinage, N. "Fracture criterion for glass under impact loading." International Journal of Impact Engineering, 25(2001):831-45.

[23] Camacho, G. T., Ortizt, M. "Computational modelling of impact damage in brittle materials." International. Journal. Solids Structures, 33(1996):2899-938.

[24] Kim, M.S., Shin, H.S., Lee, H.C. "The effects of back plate materials on perfect cone formation in impact-loaded soda-lime glass." International Journal of Impact Engineering, 28(2003):281-90.

[25] Ball, A., McKenzie, H.W. "On the low velocity impact behaviour of glass plates." Journal De Physique IV, Colloque C8, supplement au Journal de Physique III, 4(1994):783-88.

[26] Hu, W., Wang, Y., Yu, J., Yen, C-F, Bobaru, F. "Impact damage on a thin glass plate with a thin polycarbonate backing." International Journal of Impact Engineering, 62 (2013): 15265. 